\title{
Roving Survey for Turmeric Root-Knot Nematode in Major Districts of Karnataka, India
}

\author{
K.J. Niranjana Prabhu ${ }^{1 *}$, V. Kantharaju ${ }^{1}$, Y.S. Mahesh ${ }^{2}$, \\ T.N. Pushpa ${ }^{1}$ and N. Thammaiah ${ }^{3}$
}

\author{
${ }^{1}$ K. R. C College of Horticulture, Arabhavi- 591218, Karnataka, India \\ ${ }^{2}$ College of Horticulture, Bagalkot- 587104, Karnataka, India \\ ${ }^{3}$ College of Horticulture, Mysore- 571130, Karnataka, India
}

*Corresponding author

\section{A B S T R A C T}

\section{Keywords \\ Root-knot, \\ Turmeric, \\ Nematode, \\ Meloidogyne}

Article Info

Accepted:

10 December 2017

Available Online:

10 January 2018
Turmeric is one of the important spice crops grown in India. Root-knot nematode (Meloidogyne spp.) is a major problem, which causes galls/knots in the rhizomes and causes considerable yield loses. It also makes the way for the secondary infection by different pathogens like Pythium, Fusarium and Ralstonia in the soil. Yield losses due to nematode infestation are reported in turmeric-growing areas. A roving survey was conducted for incidence of root-knot nematode in turmeric during kharif season in 2016 at Belagavi, Bagalkot, Chamarajanagar and Kalburgi districts of Karnataka. Survey conducted in 38 villages comprising 118 fields, the major symptoms recorded during survey are having large root galls, stunted growth, yellowing, marginal and tip drying of leaves and reduced tillering with galling and rotting of roots. The results revealed that highest root-knot index was recorded in Chamarajanagara followed by belagavi, Bagalkot and Kalburgi districts. The lowest disease incidence was observed in Kalburgi.

\section{Introduction}

Turmeric (Curcuma longa L.) is one of the important spice crops grown in India since the times immemorial. It is an herbaceous perennial plant, native to tropical south-east Asia belonging to the family Zingiberaceae. It is regarded as a symbol of well-being and future and is widely used in ceremonies and religious functions. Medicinally, it acts as carminative, antiseptic and antiparasitic for many skin infections. It cures the sore throat, common cold and used as an appetizer and helps in digestion. It is also used in the preparation of cosmetics, soaps, skin ointments and tooth pastes.

Turmeric is cultivated mainly in India, Pakistan, Jamaica, Sri Lanka, Indonesia, Bangladesh, Taiwan and China. India is the world's largest producer of turmeric and accounts for 80 per cent of the world production. It is grown in an area of 2.33 lakh hectares with a production of 11.90 lakh 
metric tons and the productivity of 5.1 metric tons per hectare (Anon, 2015a). In India, turmeric is mainly grown in Tamil Nadu, Karnataka, Assam, Kerala, Maharashtra, Orissa and Andhra Pradesh. In Karnataka, it is grown in an area of 14.00 thousand hectares with an production of 65.00 thousand MT having productivity of $4.68 \mathrm{MT}$ per hectare (Anon, 2015a). The major turmeric producing districts of the state are Charmarajnagar, Mysuru, Bagalkot, Belagavi, Bidar and Kalburgi (Anon., 2015b).

The root-knot nematode (Meloidogyne spp.) is a major problem, which causes galls or knots in the rhizomes and causes considerable yield loses. It also plays the way for the secondary infection by different pathogens like Pythium, Fusarium and Ralstonia in the soil (Udo and Ugwuoke, 2010).

A survey is necessary to assess the community structure of plant parasitic nematodes associated with turmeric crops. Many biotic and abiotic factors such as soil temperature, soil moisture, soil type, cultural practices, weed hosts and intercropping are known to influence nematode distribution. The survey on root-knot nematode will provide information on incidence, severity and distribution.

\section{Materials and Methods}

The roving survey was undertaken to know the occurrence of root-knot nematodes associated with turmeric crop in Chamarajanagara, Bagalkot, Belagavi and Kalburgi districts of Karnataka (Fig. 1) during 2016-2017. Samples comprising soil and root system were collected from rhizosphere of turmeric crop. The sampling was done in plants showing nematode symptoms viz., yellowing, poor growth or stunted growth with reduced leaf size, chlorosis of foliage, wilting and root galls.
In each district, ten villages were selected and in each village, four soil and root samples were collected from different farmer's fields.

\section{Collection of soil and root samples}

Soil and root system samples from 3 to 5 spots were collected randomly with the aid of shovel from the root zone of standing turmeric crop. Later, a composite sample of 200 cc soil and root system were put in a polythene bag with proper labelling. Information pertaining to the crop, locality, soil condition etc., was also collected along with the samples.

\section{Estimation of nematode population in soil samples}

Soil sample of $200 \mathrm{cc}$ was washed thoroughly and processed using combined "Cobb's sieving and Baermann's funnel method" (Ayoub, 1977) as given below.

Two hundred cc of soil was taken in $1000 \mathrm{ml}$ beaker and sufficient quantity of water was added to make soil solution.

This was stirred thoroughly and allowed to stand for heavier particles to settle down.

Then the soil solution was passed through a set of sieves of 100, 250, 325 and 400 mesh sizes, respectively.

Residue from 325 and 400 mesh sieves were collected and poured over a tissue paper spread on a wire gauge and placed on Baermann's funnel.

Level of water in the Baermann's funnel was maintained to keep the tissue paper wet and left undisturbed for $48 \mathrm{hr}$.

After incubation of $48 \mathrm{hr}$, the volume of suspension was made to $200 \mathrm{ml}$, out of which $10 \mathrm{ml}$ was pipetted out and used for counting 
of various plant parasitic nematodes present. Nematode population from this was finally estimated for $200 \mathrm{cc}$ soil.

\section{Estimation of nematode population in root samples}

Nematode population in $10 \mathrm{~g}$ roots was estimated by Root incubation method (Ayoub, 1977) as explained below:

\section{Procedure}

Roots were gently washed to remove adhering soil particles.

Washed roots were cut into small bits of 2.5 $\mathrm{cm}$ and split longitudinally.

Then placed over tissue paper spread on a wire gauge and kept in a Petri plate filled with water.

Level of water was maintained in Petri plate and left undisturbed for 48 hours.

Later, the suspension in the Petri plate was collected and observed for nematodes using stereo-binocular microscope.

\section{Counting the number of nematodes}

The number of nematodes in an aqueous suspension was determined by using a counting dish. A five $\mathrm{cm}$ diameter glass Petri plate was used as a counting dish. Squares were made on the outer surface of the bottom of the dish to facilitate counting. A $10 \mathrm{ml}$ volume of aqueous suspension from the beaker was taken and placed into the petriplate. Nematodes were counted in all squares under a stereo-binocular microscope. After counting, the suspension was transferred back to the mother container. Counting of each sample was repeated four times in same manner. The mean number of nematodes per
$10 \mathrm{ml}$ was determined by averaging the counts taken.

\section{Results and Discussion}

A roving survey was carried out to know the occurrence of root-knot nematode in major turmeric growing districts viz., Chamarajanagara, Bagalkot, Belagavi and Kalburgi during Kharif 2016 and the data obtained are depicted in Table 1. The soil and root samples were collected from different places and brought to the laboratory for analysis. The presence of root-knot nematodes was assessed.

In Chamarajanagara district, the number of galls per root system was ranged from 0-82. Maximum number of galls (82) was recorded in Shivapura (b) field followed by Shivapura (c) field (78). No galls were recorded in Kodehalli (c) and Belavadi (a) fields and minimum number of galls were recorded in Gundlupet (a) field (5).

The nematode population per $200 \mathrm{cc}$ soil was ranged from 0-176. The maximum soil nematode population (176) was recorded in Shivapura (c) field followed by Shivapura (b) field (172) as against minimum population (15) in Belavadi (b) field.

On an average, the number of galls per root system was 26.26, gall index of 3.0 and soil nematode population of 73.30 recorded in Chamarajanagara district.

In Bagalkot district, the number of galls per root system was ranged from 4-32 with the maximum (32) in Jamakhandi (a) field followed by Sasalatti (b) field (25). The least number of galls was recorded in Mudhol (b) field (4).

Soil nematode population was ranged from 18-96. The maximum population (96) was 
recorded in Bisnal (c) field followed by Bisnal (b) field (95) whereas the least of nematode population (18) was recorded in Mudhol (b) field.

On an average, the number of galls per root system (19.10) gall index (2.96) and soil nematode population per $200 \mathrm{cc}$ of soil (57.30) was recorded in Bagalkot district. The results of the survey in Belagavi district revealed that, the number of galls per root system was ranged from 0-54 with Kalloli (b) field was highest (54) followed by Kalloli (c) field (52).

The least number of galls per root system was recorded in Alagavadi (b) field (10) and zero galls were recorded in Raibagh (b), Devapura (b) and Alagavadi (e) fields.

Fig.1 Roving survey for root-knot nematode incidence in turmeric in major growing districts of Karnataka

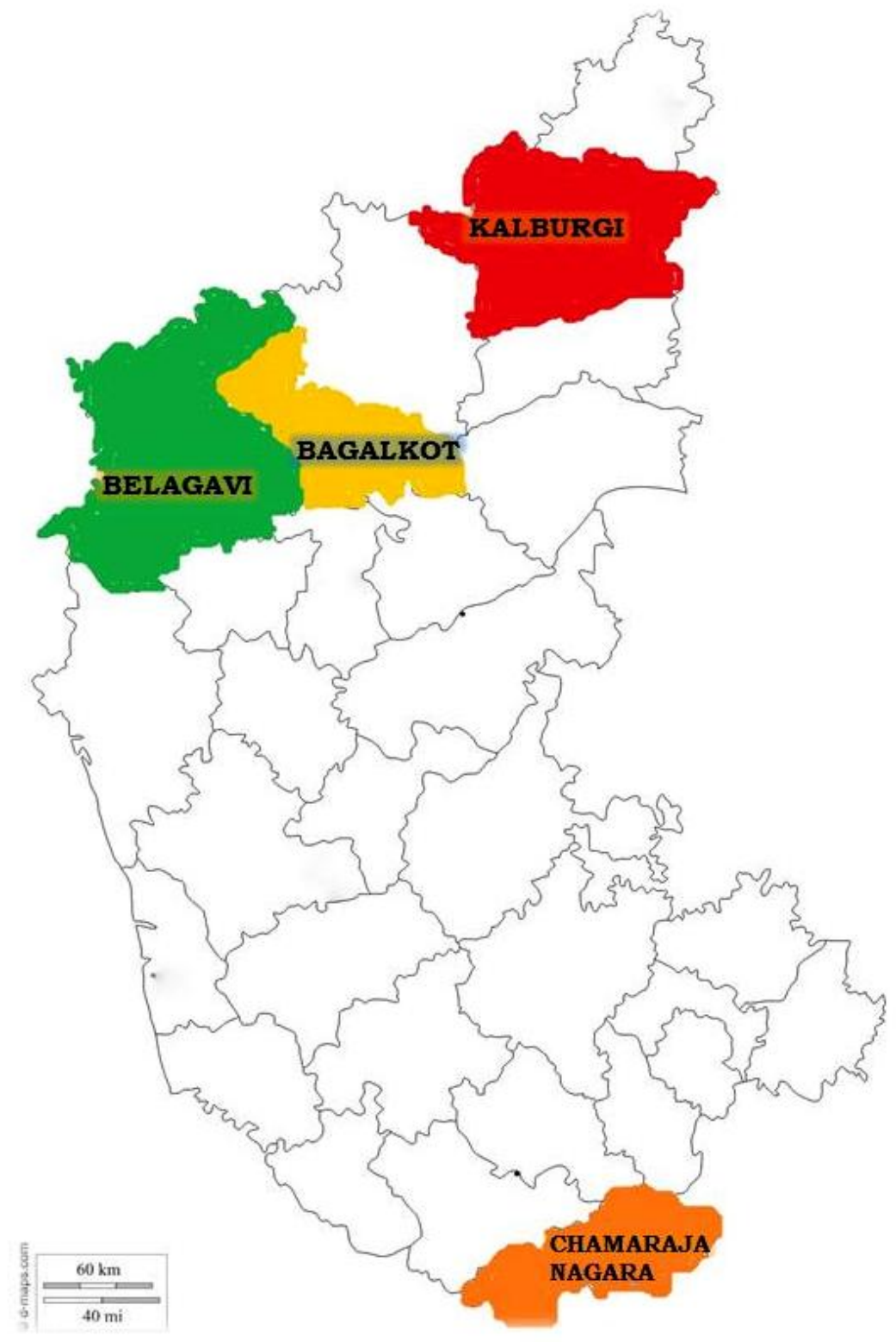


Table.1 Roving survey of root-knot nematode in major turmeric growing districts of Karnataka

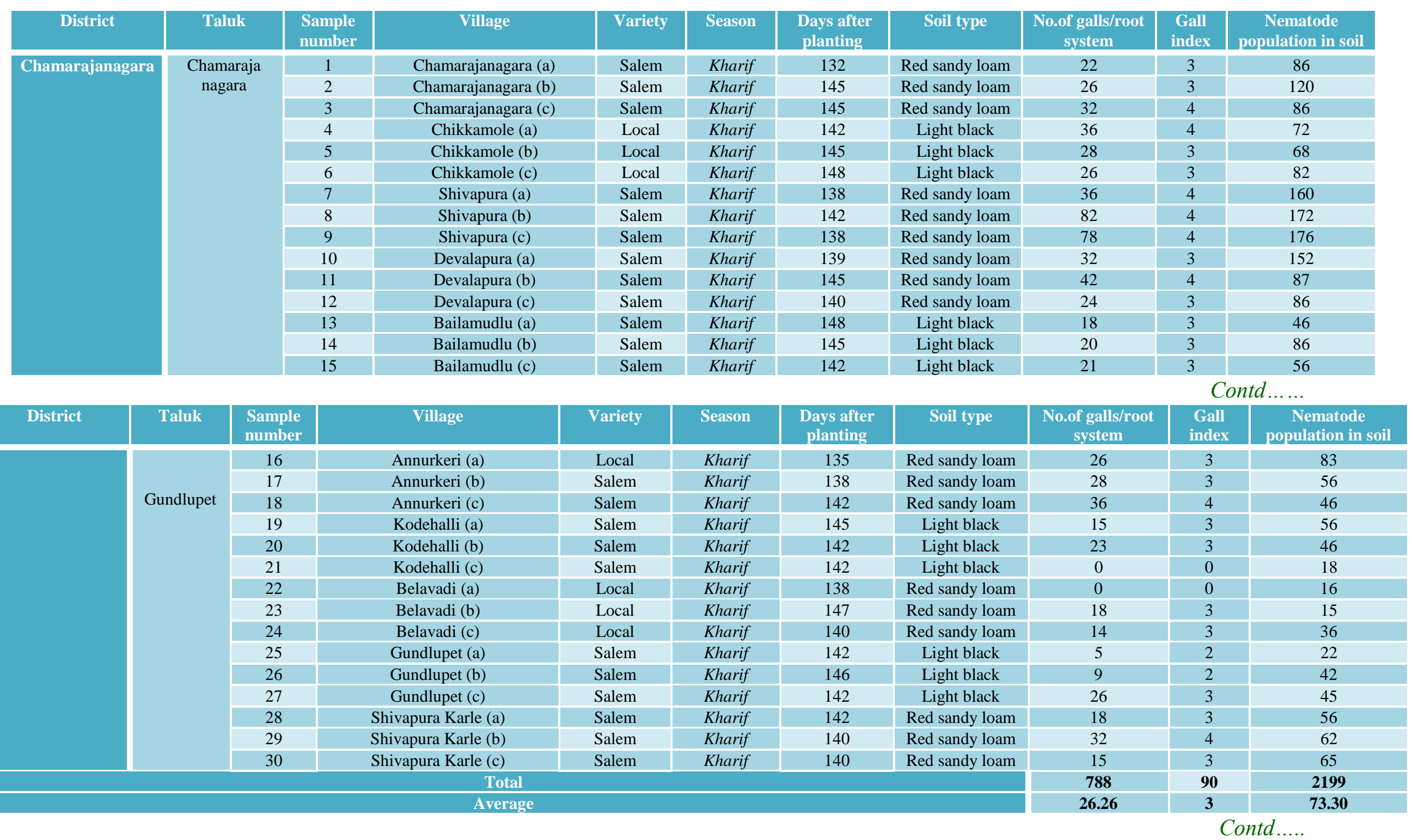


Int.J.Curr.Microbiol.App.Sci (2018) 7(1): $901-910$

\begin{tabular}{|c|c|c|c|c|c|c|c|c|c|c|}
\hline District & Taluk & $\begin{array}{l}\text { Sample } \\
\text { number }\end{array}$ & Village & Variety & Season & $\begin{array}{c}\text { Days } \\
\text { after } \\
\text { planting }\end{array}$ & Soil type & $\begin{array}{c}\text { No.of } \\
\text { galls/root } \\
\text { system }\end{array}$ & $\begin{array}{c}\text { Gall } \\
\text { index }\end{array}$ & $\begin{array}{c}\text { Nematode } \\
\text { population } \\
\text { in soil }\end{array}$ \\
\hline \multirow[t]{15}{*}{ Bagalkot } & \multirow{15}{*}{ Mudhol } & 31 & Bisnal (a) & Salem & Kharif & 140 & Medium black & 19 & 3 & 78 \\
\hline & & 32 & Bisnal (b) & Salem & Kharif & 128 & Medium black & 21 & 3 & 95 \\
\hline & & 33 & Bisnal (c) & Salem & Kharif & 122 & Medium black & 22 & 3 & 96 \\
\hline & & 34 & Mudhol (a) & Salem & Kharif & 130 & Medium black & 18 & 3 & 65 \\
\hline & & 35 & Mudhol (b) & Salem & Kharif & 132 & Medium black & 4 & 2 & 18 \\
\hline & & 36 & Mudhol (c) & Salem & Kharif & 126 & Medium black & 16 & 3 & 65 \\
\hline & & 37 & Halluru (a) & Cudappa & Kharif & 137 & Medium black & 6 & 2 & 46 \\
\hline & & 38 & Halluru (b) & Salem & Kharif & 132 & Medium black & 17 & 3 & 42 \\
\hline & & 39 & Halluru (c) & Salem & Kharif & 130 & Medium black & 18 & 3 & 36 \\
\hline & & 40 & Shirol (a) & Salem & Kharif & 140 & Medium black & 12 & 3 & 42 \\
\hline & & 41 & Shirol (b) & Salem & Kharif & 142 & Medium black & 21 & 3 & 42 \\
\hline & & 42 & Shirol (c) & Salem & Kharif & 140 & Medium black & 16 & 3 & 28 \\
\hline & & 43 & Jannuru (a) & Salem & Kharif & 145 & Medium black & 21 & 3 & 44 \\
\hline & & 44 & Jannuru (b) & Cudappa & Kharif & 145 & Medium black & 22 & 3 & 42 \\
\hline & & 45 & Jannuru (c) & Salem & Kharif & 142 & Medium black & 24 & 3 & 42 \\
\hline & & & & & & & & & \multicolumn{2}{|c|}{ Contd...... } \\
\hline District & Taluk & $\begin{array}{l}\text { Sample } \\
\text { number }\end{array}$ & Village & Variety & Season & $\begin{array}{c}\text { Days } \\
\text { after } \\
\text { planting }\end{array}$ & Soil type & $\begin{array}{c}\text { No.of } \\
\text { galls/root } \\
\text { system }\end{array}$ & $\begin{array}{c}\text { Gall } \\
\text { index }\end{array}$ & $\begin{array}{l}\text { Nematode } \\
\text { population } \\
\text { in soil }\end{array}$ \\
\hline & \multirow{15}{*}{ Jamakhandi } & 46 & Jamakhandi (a) & Salem & Kharif & 130 & Medium black & 32 & 4 & 86 \\
\hline & & 47 & Jamakhandi (b) & Salem & Kharif & 140 & Medium black & 21 & 3 & 45 \\
\hline & & 48 & Jamakhandi (c) & Salem & Kharif & 132 & Medium black & 23 & 3 & 66 \\
\hline & & 49 & Sasalatti (a) & Salem & Kharif & 140 & Medium black & 24 & 3 & 80 \\
\hline & & 50 & Sasalatti (b) & Salem & Kharif & 135 & Medium black & 25 & 3 & 56 \\
\hline & & 51 & Sasalatti (c) & Cudappa & Kharif & 138 & Medium black & 20 & 3 & 48 \\
\hline & & 52 & Golbavi (a) & Salem & Kharif & 142 & Red sandy loam & 16 & 3 & 56 \\
\hline & & 53 & Golbavi (b) & Salem & Kharif & 144 & Red sandy loam & 18 & 3 & 60 \\
\hline & & 54 & Golbavi (c) & Salem & Kharif & 135 & Red sandy loam & 19 & 3 & 75 \\
\hline & & 55 & Terdhal (a) & Salem & Kharif & 140 & Medium black & 23 & 3 & 96 \\
\hline & & 56 & Terdhal (b) & Salem & Kharif & 135 & Medium black & 18 & 3 & 82 \\
\hline & & 57 & Terdhal (c) & Salem & Kharif & 138 & Medium black & 16 & 3 & 76 \\
\hline & & 58 & Harogeri (a) & Cudappa & Kharif & 142 & Medium black & 9 & 2 & 24 \\
\hline & & 59 & Harogeri (b) & Salem & Kharif & 139 & Medium black & 19 & 3 & 46 \\
\hline & & 60 & Harogeri (c) & Salem & Kharif & 142 & Medium black & 17 & 3 & 42 \\
\hline \multicolumn{8}{|c|}{ Total } & 573 & 89 & 1719 \\
\hline \multicolumn{8}{|c|}{ Average } & 19.10 & 2.96 & $\mathbf{5 7 . 3 0}$ \\
\hline
\end{tabular}


Int.J.Curr.Microbiol.App.Sci (2018) 7(1): $901-910$

\begin{tabular}{|c|c|c|c|c|c|c|c|c|c|c|}
\hline District & Taluk & $\begin{array}{l}\text { Sample } \\
\text { number }\end{array}$ & Village & Variety & Season & $\begin{array}{l}\text { Days after } \\
\text { planting }\end{array}$ & Soil type & $\begin{array}{c}\text { No.of } \\
\text { galls/root } \\
\text { system }\end{array}$ & $\begin{array}{c}\text { Gall } \\
\text { index }\end{array}$ & $\begin{array}{c}\text { Nematode } \\
\text { population in } \\
\text { soil }\end{array}$ \\
\hline \multirow[t]{17}{*}{ Belagavi } & \multirow[t]{17}{*}{ Gokak } & 61 & Arabhavi (a) & Salem & Kharif & 142 & Medium black & 18 & 3 & 42 \\
\hline & & 62 & Arabhavi (b) & Salem & Kharif & 139 & Medium black & 16 & 3 & 68 \\
\hline & & 63 & Arabhavi (c) & Salem & Kharif & 140 & Medium black & 12 & 3 & 58 \\
\hline & & 64 & Rajapura (a) & Salem & Kharif & 142 & Medium black & 17 & 3 & 64 \\
\hline & & 65 & Rajapura (b) & Salem & Kharif & 140 & Medium black & 19 & 3 & 46 \\
\hline & & 66 & Rajapura (c) & Salem & Kharif & 136 & Medium black & 21 & 3 & 40 \\
\hline & & 67 & Tukkanatti (a) & Salem & Kharif & 128 & Medium black & 23 & 3 & 45 \\
\hline & & 68 & Tukkanatti (b) & Salem & Kharif & 130 & Medium black & 28 & 3 & 65 \\
\hline & & 69 & Tukkanatti (c) & Salem & Kharif & 132 & Medium black & 31 & 4 & 86 \\
\hline & & 70 & Tukkanatti (d) & Salem & Kharif & 135 & Medium black & 46 & 4 & 86 \\
\hline & & 71 & Tukkanatti (e) & Salem & Kharif & 138 & Medium black & 48 & 4 & 106 \\
\hline & & 72 & Kalloli (a) & Salem & Kharif & 136 & Medium black & 36 & 4 & 85 \\
\hline & & 73 & Kalloli (b) & Salem & Kharif & 140 & Medium black & 54 & 4 & 116 \\
\hline & & 74 & Kalloli (c) & Salem & Kharif & 135 & Medium black & 52 & 4 & 118 \\
\hline & & 75 & Mudalagi (a) & Salem & Kharif & 142 & Medium black & 13 & 3 & 56 \\
\hline & & 76 & Mudalagi (b) & Salem & Kharif & 142 & Medium black & 15 & 3 & 62 \\
\hline & & 77 & Mudalagi (c) & Salem & Kharif & 140 & Medium black & 16 & 3 & 72 \\
\hline
\end{tabular}

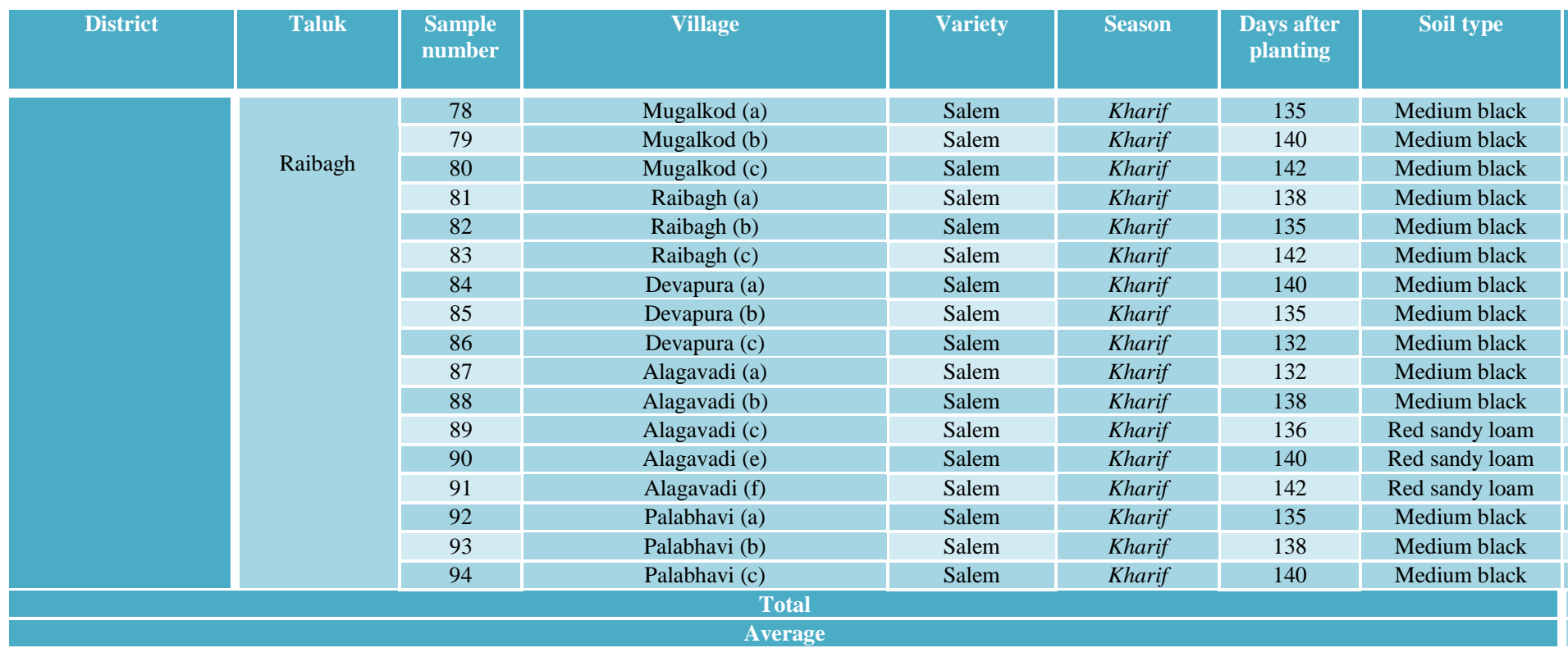

A verage

Contd.....

\begin{tabular}{|c|c|c|}
\hline $\begin{array}{c}\text { No.of } \\
\text { galls/root } \\
\text { system }\end{array}$ & $\begin{array}{c}\text { Gall } \\
\text { index }\end{array}$ & $\begin{array}{c}\text { Nematode } \\
\text { population } \\
\text { in soil }\end{array}$ \\
\hline 16 & 3 & 36 \\
\hline 18 & 3 & 46 \\
\hline 11 & 3 & 28 \\
\hline 15 & 3 & 18 \\
\hline 0 & 0 & 12 \\
\hline 16 & 3 & 26 \\
\hline 21 & 3 & 28 \\
\hline 0 & 0 & 0 \\
\hline 18 & 3 & 25 \\
\hline 16 & 3 & 40 \\
\hline 10 & 2 & 15 \\
\hline 12 & 3 & 22 \\
\hline 0 & 0 & 6 \\
\hline 16 & 3 & 28 \\
\hline 18 & 3 & 36 \\
\hline 21 & 3 & 46 \\
\hline 12 & 3 & 26 \\
\hline $\mathbf{6 8 5}$ & $\mathbf{9 8}$ & $\mathbf{1 6 5 3}$ \\
\hline $\mathbf{2 0 . 1 4}$ & $\mathbf{2 . 8 8}$ & $\mathbf{4 8 . 6 1}$ \\
\hline
\end{tabular}

Contd..... 


\begin{tabular}{|c|c|c|c|c|c|c|c|c|c|c|}
\hline District & Taluk & $\begin{array}{l}\text { Sample } \\
\text { number }\end{array}$ & Village & Variety & Season & $\begin{array}{c}\text { Days } \\
\text { after } \\
\text { planting }\end{array}$ & Soil type & $\begin{array}{c}\text { No.of } \\
\text { galls/root } \\
\text { system }\end{array}$ & $\begin{array}{c}\text { Gall } \\
\text { index }\end{array}$ & $\begin{array}{c}\text { Nematode } \\
\text { population } \\
\text { in soil }\end{array}$ \\
\hline \multirow[t]{16}{*}{ Kalburgi } & \multirow[t]{15}{*}{ Chincholi } & 95 & Ainalli (a) & Salem & Kharif & 140 & Medium black & 9 & 2 & 18 \\
\hline & & 96 & Ainalli (b) & Salem & Kharif & 140 & Medium black & 6 & 2 & 16 \\
\hline & & 97 & Ainalli (c) & Salem & Kharif & 132 & Medium black & 0 & 0 & 16 \\
\hline & & 98 & Kalluru (a) & Salem & Kharif & 130 & Medium black & 0 & 0 & 12 \\
\hline & & 99 & Kalluru (b) & Salem & Kharif & 142 & Medium black & 0 & 0 & 16 \\
\hline & & 100 & Kalluru (c) & Salem & Kharif & 136 & Medium black & 0 & 0 & 10 \\
\hline & & 101 & Chincholi (a) & Salem & Kharif & 140 & Medium black & 0 & 0 & 8 \\
\hline & & 102 & Chincholi (b) & Salem & Kharif & 137 & Medium black & 0 & 0 & 5 \\
\hline & & 103 & Chincholi (c) & Salem & Kharif & 135 & Medium black & 0 & 0 & 9 \\
\hline & & 104 & Degalamadi (a) & Salem & Kharif & 140 & Medium black & 0 & 0 & 2 \\
\hline & & 105 & Degalamadi (b) & Salem & Kharif & 137 & Medium black & 0 & 0 & 0 \\
\hline & & 106 & Degalamadi (c) & Salem & Kharif & 142 & Medium black & 0 & 0 & 12 \\
\hline & & 107 & Pinolli (a) & Salem & Kharif & 140 & Medium black & 0 & 0 & 8 \\
\hline & & 108 & Pinolli (b) & Salem & Kharif & 140 & Medium black & 0 & 0 & 6 \\
\hline & & 109 & Pinolli (c) & Salem & Kharif & 135 & Medium black & 0 & 0 & 6 \\
\hline & & & & & & & & & \multicolumn{2}{|c|}{ Contd..... } \\
\hline District & Taluk & $\begin{array}{l}\text { Sample } \\
\text { number }\end{array}$ & Village & Variety & Season & $\begin{array}{c}\text { Days } \\
\text { after } \\
\text { planting }\end{array}$ & Soil type & $\begin{array}{l}\text { No.of } \\
\text { galls/roo } \\
\text { t system }\end{array}$ & $\begin{array}{l}\text { Gall } \\
\text { index }\end{array}$ & $\begin{array}{l}\text { Nematode } \\
\text { population } \\
\text { in soil }\end{array}$ \\
\hline & \multirow{9}{*}{ Aland } & 110 & Aland (a) & Salem & Kharif & 140 & Medium black & 0 & 0 & 12 \\
\hline & & 111 & Aland (b) & Salem & Kharif & 142 & Medium black & 0 & 0 & 6 \\
\hline & & 112 & Aland (c) & Salem & Kharif & 137 & Medium black & 0 & 0 & 6 \\
\hline & & 113 & Kadaganchi (a) & Salem & Kharif & 142 & Medium black & 0 & 0 & 8 \\
\hline & & 114 & Kadaganchi (b) & Salem & Kharif & 145 & Medium black & 0 & 0 & 0 \\
\hline & & 115 & Kadaganchi (c) & Salem & Kharif & 142 & Medium black & 0 & 0 & 0 \\
\hline & & 116 & Belamagi (a) & Salem & Kharif & 135 & Medium black & 18 & 3 & 25 \\
\hline & & 117 & Belamagi (b) & Cudappa & Kharif & 140 & Medium black & 21 & 3 & 18 \\
\hline & & 118 & Belamagi (c) & Salem & Kharif & 142 & Medium black & 16 & 3 & 24 \\
\hline \multicolumn{8}{|c|}{ Total } & 70 & 13 & 243 \\
\hline \multicolumn{8}{|c|}{ Average } & 2.91 & 0.54 & 10.10 \\
\hline \multicolumn{8}{|c|}{ Grand total } & 2100 & 289 & 5914 \\
\hline \multicolumn{8}{|c|}{ Average } & 17.70 & 2.44 & 50.11 \\
\hline
\end{tabular}


Incidence of root-knot nematode was recorded by using the gall index given by (Taylor and Sasser, 1978) which is as follows

\begin{tabular}{|l|l|}
\hline Description & Grade \\
\hline No galls or egg masses & 0 \\
\hline 1 to 2 galls or egg masses & 1 \\
\hline $\mathbf{3}$ to 10 galls or egg masses & 2 \\
\hline 11 to $\mathbf{3 0}$ galls or egg masses & 3 \\
\hline $\mathbf{3 1}$ to $\mathbf{1 0 0}$ galls or egg masses & 4 \\
\hline More than 100 galls or egg masses & 5 \\
\hline
\end{tabular}

The highest soil nematode population was observed in Kalloli (c) field (118) followed by Kalloli (b) field (116), whereas least population (6) from Alagavadi (e) field and no population in Devapura (b) field.

In Belagavi district, on an average, the number of galls per root system was 20.14, gall index of 2.88 and soil nematode population of 48.61 was recorded.

In Kalburgi district the highest number of galls per root system was recorded in Belamagi (b) field (21) followed by Belamagi (a and c) fields (18 and16) respectively. No galls were recorded in Ainalli (c), Kalluru (a, $\mathrm{b}$ and c), Chincholli ( $\mathrm{a}, \mathrm{b}$ and $\mathrm{c}$ ), Degalmadi ( $a, b$ and $c$ ), Pinolli ( $a, b$ and $c)$, Aland ( $a, b$ and c) and Kadaganchi (a, b and c) fields.

Maximum soil nematode population was recorded in Belamagi (a) field (25) followed by Belamagi (c) field (24) as against no population in Degalamadi (b), Kadaganchi (b and $\mathrm{c}$ ). The minimum population was recorded in Degalmadi (a) field (2).

In Kalburgi district, on an average, the number of galls per root system was 2.91, gall index of 0.54 and nematode population of 10.10 was recorded.

On an average, among all the four districts surveyed, the maximum number of galls per root system (26.26), gall index (3.00) and soil nematode population (76.63) was seen in Chamarajanagara district followed by Belagavi (20.14, 2.88, 48.61) and Bagalkot (19.10, 2.96, 57.30) as against minimum population in Kalburgi $(2.91,0.54,10.10)$ respectively.

Present results are in conformity with the results of by Zarina and Shaheen (2014) who reported infestation of root-knot nematode in turmeric and black pepper. Yellowing, marginal and tip necrosis, reduced tillering in stunted growth, root galling and rotting are the principal symptoms of the infestation by M. incognita on turmeric (Mani et al., 1987). Population density of $M$. incognita on turmeric increased with age of the crop and decreased crop resistance (Poornima and Sivagami, 1999). Takur and Sharma (2015) reported the plant parasitic nematodes associated with ginger in the mid hill region of Himachal Pradesh. The record of severe incidence of root-knot nematode, $M$. incognita was observed in crops such as pepper, cardamom, ginger, turmeric, clove, cinnamon and nutmeg (Sundararaiu et al., 1979).

The present study revealed the prevalence of Meloidogyne incognitain most of the area surveyed and their recovery from turmeric field suggest that the nematode might have been introduced from one place to another place through soil, irrigation water, workers, infected plants and multiplied at faster rate as 
Meloidogyne incognita is having wide host range, the survival and multiplication rate will be more.

The lowest incidence of root-knot nematode was observed in Kalburgi district may be due higher temperature which is responsible for soil solarization and crop rotation, dry weather conditions. The maximum incidence of root-knot neatode was recorded from Chamarajanagara district may be due to mono cropping, suitable temperature, irrigation facilities and soil conditions.

\section{References}

Anonymous, 2015a. District wise crop production statistics, http://data.gov.in/ catalog

Anonymous, 2015b. Indian horticulture database, www.nhb.gov.in.

Ayoub, R. M., 1977. Plant Pathology An Agricultural training Aid. State California, Dept. Food and Agric. Sacromento, USA, p.156.

Mani A, P. H., Naidu and Madhavachari, S., 1987. Occurrence and control of Meloidogyne incognita on turmeric in Andhra Pradesh, India. Inter. Nematol.
Network Newslett., 2: 11-12.

Poornima, K., Sivagami, V., 1999. Occurrence and seasonal population behavior of phytone-matodes in turmeric (Curcuma longa L.).Pest Manage Hort. Ecosyst. 5: 42-45.

Sundararaju, P., Koshy, P. K. and Sosamma, V. K., 1979. Plant parasitic nematodes associated with spices. Journal of Plantation Crops, 7: 15-25.

Taylor, A. L. and Sasser, N., 1978. Biology, Identification and control of Root- Knot Nematodes (Meloidogyne spp.) North Carolina State Univ., Graphics, p. 111.

Thakur, N and Sharma, G. C., 2015. Status of plant parasitic nematodes in ginger fields of Himachal Prdesh, Int. J. Sci. Env. Tech., 4(4): 976 - 979.

Udo, I. A. and Ugwuoke, K. I., 2010. Pathogenicity of Meloidogyne incognita Race 1 on turmeric (Curcuma longa L.) as influenced by inoculum density and poultry manure amendment. Plant Pathology J., 9: 162-168.

Zarina, B. and Shaheen, N., 2014. Spice plants as new host record of Meloidogyne incognita in Pakistan. Int. J. Biology and Biotechnol., 11(3): 449.

\section{How to cite this article:}

Niranjana Prabhu, K.J., V. Kantharaju, Y.S. Mahesh, T.N. Pushpa and Thammaiah, N. 2018. Roving Survey for Turmeric Root-Knot Nematode in Major Districts of Karnataka. Int.J.Curr.Microbiol.App.Sci. 7(01): 901-910. doi: https://doi.org/10.20546/ijcmas.2018.701.110 